\title{
DETERMINAN GAYA HIDUP SEHAT KONSUMEN ORGANIK
}

\author{
Tony Wijaya (Tonypascamm@yahoo.com) \\ STIE IEU Yogyakarta
}

\begin{abstract}
Abstrak
Penelitian ini bertujuan untuk menguji pengaruh nilai orientasi alami manusia terhadap sikap pada makanan organik dan pengaruh sikap pada makanan organik terhadap gaya hidup sehat. Data dikumpulkan melalui survei menggunakan kuesioner. Responden dalam penelitian ini adalah konsumen makanan organik yang berdomisili di DIY dan Jawa Tengah. Alat analisis dalam penelitian ini menggunakan Structural Equation Modeling (SEM).

Hasil analisis data menunjukkan bahwa nilai orientasi alami manusia berpengaruh secara positif dan signifikan terhadap sikap pada makanan organik, dan sikap pada makanan organik memiliki pengaruh yang positif dan signifikan terhadap gaya hidup sehat.
\end{abstract}

Kata-kata kunci: Nilai orientasi alami manusia, Sikap, Gaya hidup sehat, makanan organik

\section{PENDAHULUAN}

Pola hidup sehat dengan slogan "back to nature" atau kembali ke alam telah menjadi tren masyarakat dunia. Pola hidup ini didasari bahwa segala sesuatu yang berasal dari alam adalah baik dan berguna serta menjamin adanya keseimbangan antara manusia dan alam (Chan 2001). Kesadaran masyarakat akan gaya hidup sehat akhir-akhir ini mulai meningkat (Rifai et al. 2008). Manusia semakin menyadari bahwa penggunaan bahan-bahan kimia non alami seperti pestisida kimia dalam produksi pertanian menimbulkan efek negatif terhadap kesehatan manusia dan lingkungan.

Penggunaan pestisida seperti insektisida, fungisida dan herbisida untuk membasmi hama tanaman, hewan, dan gulma (tanaman benalu) sering menimbulkan komplikasi lingkungan (Supardi 1994). Beberapa hasil penelitian melaporkan adanya sejumlah residu insektisida permetrin pada tomat dan kubis, insektisida kartap hidroklorida dan endosulfan pada kubis, dan residu fungisida mankozeb pada tomat dan petai (Munarso et al. 2006). Penggunaan pestisida dalam kegiatan pertanian dapat mengakibatkan dampak negatif pada kesehatan manusia, misalnya terdapat residu pestisida pada produk pertanian dan bioakumulasi dan biomagnifikasi melalui rantai makanan. Manusia sebagai makhluk hidup yang letaknya paling ujung dari rantai makanan dapat memperoleh efek biomagnifikasi yang paling besar (Adriyani 2006).

Noorastuti \& Astuti (2010) melaporkan bahwa hasil penelitian University of Montreal di Quebec menunjukkan bahwa paparan pestisida yang digunakan pada makanan anak-anak seperti stroberi segar, seledri bisa meningkatkan risiko Attention Deficit Hyperactivity Disorder (ADHD) pada anak. Para ilmuwan di AS dan Kanada menemukan bahwa anakanak dengan tingkat residu pestisida yang tinggi dalam urin mereka, rentan mengalami ADHD. ADHD adalah gangguan perkembangan dalam peningkatan aktifitas motorik anak- 
anak. Gangguan ini berdampak pada masalah mental seperti cara berpikir, bertindak dan merasa. Anak-anak yang mengalaminya akan bermasalah dengan konsentrasi dan pemusatan pikiran. Menurut kajian National Academy of Sciences pada tahun 2008, 28\% sampel blueberry beku, 25\% sampel stroberi segar, dan 19\% sampel seledri mengandung residu pestisida. Paparan pestisida kebanyakan berasal dari buah-buahan dan sayuran segar sehingga ahli kesehatan menganjurkan untuk mengkonsumsi makanan organik.

Munculnya berbagai isu kesehatan yang melanda dunia di bidang skandal makanan, sepert krisis bovine spongy encephalopathy (BSE) atau yang lebih dikenal sebagai penyakit sapi gila, dan beberapa penyakit baru lain yang disebabkan bakteri Ecoli pada produk daging, wabah flu burung telah mendorong melonjaknya permintaan produk organik di kawasan Asia Pasifik (Winarno 2003). Perbaikan mutu kehidupan yang sehat disertai preferensi konsumen menyebabkan permintaan produk pertanian organik di seluruh dunia tumbuh rata-rata $20 \%$ per tahun.

Berbagai literatur kesehatan sebagian besar selalu menyarankan untuk mengkonsumsi makanan yang segar dan alami. Makanan yang baik adalah semua makanan segar yang memenuhi kebutuhan gizi tubuh, yaitu makanan yang mengandung unsur-unsur hidrat arang, protein, lemak, vitamin, mineral, air, dan zat-zat penting lainnya seperti serat, enzim, dan antioksidan (Gunawan 1999). Makanan yang terkontaminasi oleh pestisida akan meninggalkan residu berbahaya yang terus menumpuk di dalam tubuh manusia. Tren mengkonsumsi makanan organik memang mulai meningkat seiring dengan kesadaran terhadap pentingnya gaya hidup sehat dengan konsumsi makanan organik. Pertumbuhan permintaan produk kesehatan seperti makanan organik didorong oleh pertumbuhan segmen konsumen yang mengarah pada gaya hidup sehat (Divine \& Lepisto 2005). Gaya hidup sehat dengan cara kembali ke alam dengan mengkonsumsi makanan yang diproduksi secara alamiah sedang menjadi trend baru bagi sebagian masyarakat (Rifai et al. 2008).

Pemahaman faktor-faktor yang berperan menjelaskan gaya hidup sehat konsumen organik diharapkan mampu mengurangi degradasi lingkungan melalui aspek konsumsi. Peningkatan permintaan makanan organik yang tinggi akan memicu pertumbuhan produksi makanan organik atau dari aspek ekonomi disebut penawaran (Wijaya \& Hidayat 2011). Faktor-faktor yang berhubungan dengan gaya hidup sehat pernah dilakukan oleh penelitian sebelumnya yaitu sikap konsumen (Chen 2009; Suprapto \& Wijaya 2012b) dan nilai konsumen (Divine \& Lepisto 2005). Perilaku yang memperhatikan kualitas lingkungan hidup sangat bergantung pada tingkat pengetahuan, sikap, dan nilai yang ada pada konsumen sebagai umat manusia (Mansaray \& Abijoye 1998; Chen \& Chai 2010; Said 2003).

Sikap merupakan salah satu komponen yang digunakan untuk menjelaskan perilaku terutama gaya hidup sehat. Kontroversi hubungan sikap konsumen dan gaya hidup masih diperdebatkan. Studi empiris dari beberapa peneliti menunjukkan kesenjangan penelitian antara hubungan gaya hidup dengan sikap konsumen organik. Beberapa penelitian menunjukkan adanya hubungan positif gaya hidup dengan sikap konsumen (Beharrel \& MacFie 1991; Chen 2009; Sanjuan et al, 2003; Chryssohoidis \& Krystallis 2005; Magistris \& Gracia 2008; Suprapto \& Wijaya 2012b ;Wijaya \& Hidayat 2011). Berbeda dengan hasil penelitian Durham \& Andrade (2005) yang menemukan bahwa sikap konsumen produk organik tidak memiliki hubungan yang signifikan dengan gaya hidup. 
Chen (2009) dalam penelitiannya menemukan bahwa sikap pada lingkungan berpengaruh signifikan terhadap gaya hidup sehat, namun penelitian tersebut belum mempertimbangkan aspek nilai konsumen sebagai faktor yang menentukan perilaku yang memperhatikan kualitas lingkungan hidup (Mansaray \& Abijoye 1998; Chen \& Chai 2010; Said 2003). Konsep tentang makanan dan nutrisi memiliki nilai sosial, karena pilihan personal dipengaruhi oleh nilai-nilai personal dan nilai-nilai yang diakui lingkungan sosial (Fotopoulos \& Krystallis 2002). Secara teoritis, nilai merupakan determinan dasar dalam memprediksi perilaku sesuai konsep hirarki nilai, sikap dan perilaku (Arnould et al. 2004; Homer \& Kahle 1988).

Nilai merupakan variabel psikografis yang menjadi orientasi perusahaan dalam mengidentifikasi segmentasi konsumen untuk produk-produk yang ramah lingkungan (Engel et al. 2000; Fraj \& Martinez 2006). Nilai sering digunakan oleh mengidentifikasi perilaku konsumen ramah lingkungan untuk keperluan pemasaran. Nilai konsumen dipertimbangkan sebagai variabel penting dalam memahami perilaku konsumen sebab nilai menghadirkan tujuan yang fundamental yang konsumen cari, dan pada akhirnya untuk pemuasan bagi segmen mereka (Divine \& Lepisto 2005). Beberapa penelitian mengidentifikasi bahwa nilai yang sesuai dengan perilaku ramah lingkungan adalah nilai orientasi alami manusia (Chan 2001; Wijaya \& Hidayat 2012; Suprapto \& Wijaya 2012a). Penelitian yang dilakukan bertujuan menguji pengaruh nilai orientasi alami manusia sebagai determinan dasar terhadap gaya hidup sehat melalui sikap konsumen pada makanan organik sesuai konsep hirarki nilai, sikap dan perilaku.

\section{LANDASAN TEORI DAN PENGEMBANGAN HIPOTESIS}

\section{Hirarki Sikap, Nilai dan Perilaku}

Konsep mekanisme nilai-sikap-perilaku menjelaskan bahwa perilaku konsumen dapat diprediksi melalui nilai konsumen. Pengaruh hirarki dari nilai, sikap dan perilaku dapat ditemukan secara teoritis dan empiris dalam membahas masalah konsumen dan lingkungan. Beberapa studi menguji pengaruh nilai terhadap sikap dan perilaku ekologikal (Milfont et al. 2009). Secara spesifik, Arnould et al. (2004) dan Homer dan Kahle (1988) menjelaskan hubungan nilai dengan perilaku konsumen melalui mekanisme hirarki nilai-sikap-perilaku (The value-attitute-behavior hierarchy). Konsep nilai merupakan salah faktor yang penting dalam menjelaskan perilaku konsumen. Nilai relatif stabil dibandingkan faktor-faktor lain yang mempengaruhi perilaku konsumen.

Nilai berperan dalam membentuk sikap konsumen, kemudian mempengaruhi perilaku konsumen dalam konsumsi. Pola ini disebut juga sebagai hirarki nilai-sikap-perilaku (The value-attitute-behavior hierarchy) (Arnould et al. 2004; Homer \& Kahle 1988). Nilai merupakan pertimbangan yang fundamental bagi hubungan konsumen dengan lingkungan. Makanan organik sebagai produk ramah lingkungan merupakan elemen sistem keyakinan individu (Dembkowski \& Lloyd 1994).

Nilai merupakan faktor penting yang mendorong individu dalam melihat dunia (Engel et al. 2005; Homer \& Khale 1988). Studi literatur yang membandingkan antar negara atau antar kota mengungkapkan bahwa nilai suatu masyarakat tertentu berpengaruh pada perilaku pembelian yang memperhatikan dampak lingkungan sosial dan individu (Chan \& Lau 2000; 
Fotopoulos \& Krystallis 2000). Nilai yang dianut seseorang akan menentukan konsumsinya karena nilai-nilai merupakan manifestasi kognitif atas tuntutan-tuntutan universal manusiawi seperti biologis, interaksi sosial, dan tuntutan pranata sosial terhadap individu (Schwartz \& Bilsky 1987). Sikap individu pada umumnya didasarkan pada nilai yang dianutnya untuk membuat keputusan relevan. Dalam memprediksi perilaku konsumen, para ahli berpendapat bahwa perilaku konsumsi merupakan bagian dari gaya hidup seseorang.

\section{Nilai Orientasi Alami Manusia dan Sikap pada Makanan Organik}

Nilai merupakan pertimbangan yang fundamental bagi hubungan konsumen dengan lingkungan. Individu yang menganut nilai akan memberikan pengaruh terhadap perilaku konsumsi. Pengaruh tersebut membentuk sebuah kesadaran akan manfaat yang diperoleh setelah mengkonsumsi barang tersebut. Nilai yang dianut setiap individu akan mempengaruhi sikap, dan kemudian dari sikap tersebut akan mempengaruhi perilaku konsumsinya (Mowen \& Minor 2006).

Makanan organik sebagai produk ramah lingkungan merupakan elemen sistem keyakinan individu (Dembkowski \& Lloyd 1994). Secara tradisional keyakinan manfaat makanan dan nutrisi merupakan bagian budaya bagi bangsa Cina, Jepang, Korea dan beberapa negara Asia lainnya (Verschuren 2002; Westrate 2002). Nilai adalah kepercayaan atau segala sesuatu yang dianggap penting oleh seseorang atau masyarakat. Nilai bisa berarti sebuah kepercayaan tentang suatu hal, namun nilai bukan hanya kepercayaan. Dalam berperilaku seseorang diarahkan oleh nilai yang sesuai dengan budayanya.

Konsumen yang memperhatikan produk ramah lingkungan diharapkan memiliki nilai-nilai orientasi pada hubungan manusia dengan alam sehingga memahami dampak konsumsi produk pada lingkungan. Orientasi nilai konsumen dapat dibedakan dalam beberapa tipe yaitu man-nature orientation, man-himself orientation, relational orientation, past-time orientation, dan activity orientation. Tipe nilai yang dikemukakan oleh Kluckhohn \& Strodtbeck (1961) dalam Variations in Value Orientations, lebih banyak digunakan dalam penelitian perilaku konsumen dibandingkan tipe nilai lainnya (Churchill 1979; Engel et al. 2005). Kategorisasi yang dilakukan oleh Chan dan Lau (2000), Chan (2001) dan Sihombing (2007) menunjukkan bahwa tipe nilai menurut Kluckhohn dan Strodtbeck (1961) yang mampu memprediksi perilaku pembelian produk hijau atau ramah lingkungan adalah man nature orientation atau orientasi alami manusia.

Orientasi alami manusia (man-nature orientation) berfokus pada hubungan manusia dengan alam dan pada dasarnya manusia mengarah pada kehidupan yang harmonis dengan lingkungannya. Orientasi alami manusia memiliki dimensi subjugation to nature, harmony with nature, dan mastery over nature (Chan \& Lau 2000). Penduduk Asia memandang diri mereka sebagai bagian dari alam dan hidup harmonis dengan alam atau berorientasi pada alam (de Mooij 2004) yang disebut Chan (2001) sebagai orientasi alami manusia (Man Nature Orientation). Konsumen yang memiliki orientasi alami manusia cenderung mempertimbangkan akibat-akibat konsumsi pada lingkungan sehingga memiliki sikap ramah lingkungan (Chan 2001).

Beberapa studi menunjukkan terdapat inkonsistensi hasil penelitian hubungan nilai konsumen dengan sikap konsumen terhadap makanan organik. Nilai konsumen memiliki pengaruh yang positif terhadap sikap konsumen pada produk organik (Dreezens et al. 2005; Krystallis et al. 150 
2008; Grunert \& Juhl, 1995; Loureiro et al. 2001; Magnusson et al. 2001, 2003; Durham \& Andrade 2005; Kuhar \& Juvancic 2005; Midmore et al. 2005; Padel \& Foster 2005; Verhoef 2005; Gracia \& de Magistris 2007; Stobbelaar et al. 2007; Hidayat \& Wijaya 2012). Berbeda dengan hasil penelitian lainnya yang mengemukakan bahwa nilai konsumen tidak berpengaruh signifikan terhadap sikap konsumen pada makanan organik (Chryssohoidis \& Krystallis 2005; Baker et al. 2004).

Orientasi alami manusia berisi nilai-nilai yang mengarah pada hubungan manusia dengan alam sehingga konsumen berupaya mencari atau memperoleh informasi-informasi yang berkaitan dengan masalah lingkungan. Orientasi alami manusia berpengaruh positif terhadap sikap konsumen (Chan \& Lau 2000; Chan 2001). Dengan demikian konsumen yang memiliki orientasi nilai alami manusia akan memiliki sikap yang mendukung konsumsi produk organik (Wijaya \& Hidayat 2011; Suprapto \& Wijaya 2012a). Studi meta-analisis menunjukkan ada hubungan nilai konsumen dengan sikap terhadap produk organik yaitu sebesar 0,324. Hipotesis yang diajukan sebagai berikut:

H1: Nilai orientasi alami manusia berpengaruh positif terhadap sikap pada makanan organik

\section{Sikap pada Makanan Organik dan Gaya Hidup Sehat}

Gaya hidup menggambarkan keseluruhan diri konsumen yang berinteraksi dengan lingkungannya termasuk pola konsumsi. Pemilihan produk biasanya disesuaikan dengan gaya hidup konsumen. Para pemasar berupaya mencari hubungan jenis produk dengan gaya hidup untuk keperluan segmentasi. Konsumen mengembangkan seperangkat konsepsi untuk mengurangi ketidaksesuaian atau inkonsistensi dalam nilai dan gaya hidup mereka (Engel et al. 2005).

Gaya hidup adalah pola hidup seseorang di dunia yang diekspresikan dalam aktivitas, minat dan opini (Kotler 2006). Gaya hidup didefinisikan sebagai pola orang hidup yang menghabiskan waktu serta uang pada aktivitas tertentu dan bersifat kontemporer dan komprehensif (Engel et al. 2005). Gaya hidup menggambarkan keseluruhan diri seseorang yang berinteraksi dengan lingkungannya. Dibandingkan dengan nilai yang relatif stabil, gaya hidup cenderung lebih cepat berubah. Menurut Kasali (1998), para peneliti pasar yang menganut pendekatan gaya hidup cenderung mengklasifikasikan konsumen berdasarkan konsep AIO, yaitu aktivitas (activity), minat (interest), dan opini (opinion).

Aktivitas konsumsi konsumen yang diekspresikan dalam aktivitas, minat dan opini yang mendukung kesehatan seperti hidup seimbang, peduli dan menjaga kesehatan (Gil et al. 2000; Magistris \& Gracia 2008). Gaya hidup sehat diukur dengan indikator aktivitas, minat dan opini orientasi konsumsi sehat. Bloch (1984) mendefinisikan gaya hidup sehat sebagai orientasi pencegahan masalah kesehatan dan memaksimalkan kesejahteraan personal melalui pola konsumsi. Gaya hidup konsumsi sehat dapat didefinisikan sebagai pengertian aktivitas konsumsi yang diekspresikan dalam aktivitas, minat dan opini yang yang beorientasi pada kesehatan untuk kesejahteraan hidup.

Konsumen yang memiliki gaya hidup sehat cenderung melakukan upaya-upaya yang menyehatkan tubuh seperti berolahraga, konsumsi makan natural, serta hidup yang seimbang (Gil et al. 2000) dan memiliki sikap yang positif terhadap makanan organik. Selain itu konsumen yang memiliki gaya hidup sehat lebih mempertimbangkan segala aktivitas yang 
menunjang kesehatan. Konsumen memiliki pemikiran bahwa segala aktivitas yang dilakukan konsumen mustahil dapat menunjang kesehatan mereka jika tidak disesuaikan dengan pola konsumsi yang sehat (Chen, 2009) sehingga makanan organik merupakan objek gaya hidup sehat. Konsumen yang memiliki gaya hidup sehat cenderung memiliki sikap yang positif terhadap makanan organik (Suprapto \& Wijaya 2012b).

Chen (2009) dalam penelitiannya menemukan hubungan positif antara sikap pada makanan organik dengan gaya hidup sehat. Konsumen yang memiliki gaya hidup sehat lebih mengutamakan konsumsi makanan organik sebagai bagian dari aktivitas hidup sehat dan memiliki sikap yang positif pada makanan organik sebagai penunjang kesehatan. Hal ini juga didukung oleh hasil penelitian Magistris dan Gracia (2008) yang mengungkapkan bahwa sikap konsumen pada makanan organik memiliki hubungan positif dengan gaya hidup sehat. Hipotesis yang diajukan daam penelitian ini yaitu:

H2: Sikap pada makanan organik berpengaruh positif terhadap gaya hidup sehat

\section{METODE PENELITIAN}

\section{Paradigma Penelitian}

Paradigma dalam penelitian ini berorientasi pada paradigma positivisme yang menekankan verifikasi teori atau pengujian model. Paradigma ini mengutamakan pendekatan deduktif yang dimulai dengan melakukan abstraksi pernyataan teoritis yang luas, dan dihasilkan secara independen terhadap data (Williamson et al. 1977). Paradigma positivisme cenderung bersifat deduktif dengan mengukur fenomena dengan ketepatan variabel dan melakukan pengujian hipotesis.

\section{Metode Pengumpulan Data}

Penelitian ini menggunakan data primer. Metode pengumpulan data dilakukan dengan survei menggunakan kuesioner. Kueisoner yang didistribusikan sebanyak 300 kuesioner dan kuesioner yang kembali dan dapat dianalisis hanya sebanyak 202 kuesioner.

\section{Konstrak Variabel dan Definisi Operasional Variabel}

Tataran data variabel penelitian yang dikumpulkan berbentuk skor data rentang (interval) atau menggunakan skala interval yaitu rentang 1-5, dan definisi operasional yang berkaitan dengan arti dari seluruh variabel laten yang digunakan dalam penelitian lapangan ini dijabarkan serta dijelaskan sebagai berikut ini:

\section{Variabel Gaya Hidup Sehat $(G H)$}

Gaya hidup sehat didefinisikan sebagai aktivitas konsumsi konsumen yang diekspresikan dalam bentuk aktivitas, minat dan opini yang mendukung kesehatan yaitu keseimbangan pola makan, menghindari makanan sintetis, tertarik pada hal kesehatan makanan, hubungan konsumsi dan kesehatan, dan mengelola pola konsumsi yang sehat (Magistris \& Gracia 2008). Gaya hidup sehat diukur dengan indikator aktivitas, minat dan opini orientasi konsumsi sehat mengacu pada keseimbangan pola makan, menghindari makanan sintetis, tertarik pada hal kesehatan makanan, hubungan konsumsi dan kesehatan, dan mengelola pola konsumsi yang 
sehat. Kuesioner yang digunakan mengacu pada alat ukur yang dikembangkan oleh Magistris dan Gracia (2008) dan Suprapto \& Wijaya (2012b). Data skor variabel gaya hidup sehat diperoleh dari hasil komputasi skor jawaban butir kuesioner yang diisi oleh responden di pernyataan alat ukur penelitian. Berdasarkan hasil uji coba kuesioner dengan 128 responden diperoleh reliabilitas dengan Cronbach Alpha sebesar 0,927 dengan nilai korelasi butir berkisar 0,847-0,917.

\section{Variabel Sikap pada Makanan Organik (ATB)}

Sikap pada makanan organik yaitu perasaan atau evaluasi umum tentang membeli makanan organik berdasarkan keyakinan membeli makanan organik dari segi manfaat dan kerugian. Sikap pada makanan organik diukur dengan indikator a) yakin bahwa makanan organik bermanfaat bagi kesehatan, b) makanan organik aman dikonsumsi keluarga, c) makanan organik tidak tahan lama (cepat rusak) dan d) alami untuk dikonsumsi keluarga (Wijaya 2013). Data variabel sikap pada makanan organik diperoleh dari hasil komputasi skor jawaban aitem kuesioner yang diisi oleh responden di pernyataan kuesioner penelitian. Berdasarkan hasil uji coba kuesioner dengan 128 responden diperoleh reliabilitas dengan Cronbach Alpha sebesar 0,937 dengan nilai korelasi butir berkisar 0,832-0,864.

\section{Variabel Nilai Orientasi Alami Manusia (OAM)}

Nilai orientasi alami manusia didefinisikan sebagai tendensi hubungan manusia dengan lingkungan yang pada dasarnya akan mengarah pada kehidupan yang harmonis dalam kealamiannya (Chan \& Lau 2000) yang diukur dengan alat ukur yang dikembangkan dari survey pendahuluan dan disesuaikan kuesioner yang dikembangkan oleh Chan dan Lau, (2000). Nilai orientasi alami manusia diukur dengan indikator:

a. perlunya manusia memahami alam,

b. perlakuan terhadap alam sepantasnya,

c. menjaga keharmonisan dengan alam,

d. manusia bagian dari alam dan e) adaptasi pada alam.

Kuesioner yang digunakan mengacu pada alat ukur yang dikembangkan oleh Chan dan Lau (2000) yang disesuaikan dengan kondisi empiris di lapangan. Data skor variabel orientasi alami manusia diperoleh dari hasil komputasi skor jawaban butir alat ukur yang diisi oleh responden di pernyataan kuesioner penelitian. Berdasarkan hasil uji coba kuesioner dengan 128 responden diperoleh reliabilitas dengan Cronbach Alpha sebesar 0,886 dengan nilai korelasi butir berkisar 0,649-0,807.

\section{Populasi dan Sampel}

Populasi penelitian yang digunakan sebagai sumber sampel adalah konsumen makanan organik di DIY dan Jawa Tengah. Teknik sampel menggunakan teknik non probabilitas dengan metode purposive sampling, dan dipilih adalah konsumen yang mengetahui makanan organik dan melakukan pembelian dengan tujuan konsumsi keluarga, mengolah makanan atau memasak untuk konsumsi keluarga sehari-hari.

\section{Metode Analisis Data}

Metode analisis data dalam penelitian menggunakan analisis model persamaan struktural atau disebut Structural Equation Modeling (SEM). 


\section{HASIL PENELITIAN DAN PEMBAHASAN}

\section{Karakteristik Responden}

Sampel ditemui di sejumlah supermarket yang menyediakan makanan organik yang siap diolah seperti beras, sayur-sayuran dan buah-buahan organik. Responden yang berusia 26-30 tahun berjumlah 39 orang atau sebesar 19,3\%, responden yang berusia 36-40 tahun sebanyak 76 responden atau sebesar 37,6\%yang berusia 31-35 tahun berjumlah 36 orang atau sebesar $17,8 \%$, dan yang berusia $41-45$ tahun berjumlah 51 orang atau sebesar $25,2 \%$

Berdasarkan tingkat pendidikan responden, dapat diidentifikasi bahwa mayoritas responden memiliki pendidikan tinggi. Responden yang memiliki pendidikan SMU/setingkat sebanyak 21 orang atau sebesar 10,4\%, responden yang memiliki pendidikan Diploma (D1-D3) sebanyak 41 orang atau sebesar 20,3\%, responden yang memiliki pendidikan S1 sebanyak 95 orang atau sebesar $47,0 \%$, dan responden yang memiliki pendidikan S2 sebanyak 45 orang atau sebesar $22,3 \%$.

Berdasarkan tingkat pendapatan keluarga, mayoritas responden tergolong menengah ke atas dengan pendapatan keluarga di atas Rp.9.000.000 yaitu sebanyak 88 responden atau sebesar 43,6\%. Responden yang memiliki pendapatan Rp. 1.000.000-3.000.000 sebanyak 9 responden atau sebesar 4,4\%, responden yang memiliki pendapatan Rp. 3.000.100-5.000.000 sebanyak 12 responden atau sebesar 5,9\%. Responden yang memiliki pendapatan Rp. 5.000.100-7.000.000 sebanyak 48 responden atau sebesar 23,8\%. Responden yang memiliki pendapatan Rp. 7.000.100 - 9.000.000 sebanyak 45 responden atau sebesar 22,3\%.

\section{Uji Normalitas Data}

Normalitas data dapat diamati melalui skewness dan kurtosis value. Amatan dapat dilakukan dengan memperhatikan nilai $\mathrm{z}$ atau $\mathrm{z}$ value. Data dikatakan normal apabila memiliki nilai kritis di bawah nilai z ( $z$ value). Nilai z untuk probabilitas $1 \%$ sebesar $\pm 2,58$. Berdasarkan data uji normalitas diketahui bahwa semua data yang berasal dari data variabel manifes memiliki critical ratio atau nilai kritis di bawah $\pm 2,58$

\section{Uji Validitas dan Reliabilitas}

Tabel 1 menunjukkan nilai muatan faktor yang diukur dari variabel laten melalui masingmasing variabel terobservasi. Nilai muatan faktor berkisar dari 0,77-0,93 di atas 0,5.

Tabel. 1.

Muatan Faktor (Factor Loading)

\begin{tabular}{|l|l|l|l|}
\hline $\begin{array}{l}\text { Variabel } \\
\text { aten }\end{array}$ & $\begin{array}{l}\text { Nilai orientasi alami } \\
\text { manusia (OAM) }\end{array}$ & $\begin{array}{l}\text { Sikap pada makanan } \\
\text { organik (ATB) }\end{array}$ & Gaya hidup sehat (GH) \\
$\begin{array}{l}\text { Variabel } \\
\text { terobservasi }\end{array}$ & & & \\
\hline OAM1 & 0,91 & & \\
\hline OAM2 & 0,89 & & \\
\hline OAM3 & 0,93 & & \\
\hline
\end{tabular}




\begin{tabular}{|l|l|l|l|}
\hline OAM4 & 0,90 & & \\
\hline OAM5 & 0,91 & & \\
\hline ATB1 & & 0,92 & \\
\hline ATB2 & & 0,92 & \\
\hline ATB3 & & 0,91 & \\
\hline ATB4 & & 0,91 & \\
\hline GH1 & & 0,88 \\
\hline GH2 & & & 0,86 \\
\hline GH3 & & & 0,82 \\
\hline GH4 & & & 0,77 \\
\hline GH5 & & & 0,78 \\
\hline
\end{tabular}

Sumber: Data diolah, 2013

Reliabilitas diperlukan untuk ukuran internal konsistensi indikator suatu konstruk. Pendekatan untuk menilai model pengukuran adalah mengukur reliabilitas komposit (composite reliability) dan ekstraksi varian (variance extracted). Mengacu pada formulasi di atas dapat diketahui nilai reliabilitas komposit dan ekstraksi varian masing-masing variabel sebagai berikut:

Tabel. 2.

Koefisien Reliabilitas Komposit dan Ekstraksi Varian

\begin{tabular}{|l|c|c|c|c|}
\hline \multicolumn{1}{|c|}{ Variabel } & $\boldsymbol{\lambda}_{\mathbf{i}}$ & $\boldsymbol{\varepsilon}_{\mathbf{i}}$ & $\begin{array}{c}\text { Reliabilitas } \\
\text { komposit }\end{array}$ & $\begin{array}{c}\text { Ekstraksi } \\
\text { varian }\end{array}$ \\
\hline \multicolumn{1}{|c|}{ Nilai orientasi alami manusia $(\mathbf{O A M}) \mathbf{2}$} & & 0,95 & 0,82 \\
\hline OAM1 & 0,91 & 0,83 & & \\
\hline OAM2 & 0,89 & 0,79 & & \\
\hline OAM3 & 0,93 & 0,86 & & \\
\hline OAM4 & 0,90 & 0,81 & & 0,84 \\
\hline OAM5 & 0,91 & 0,82 & & \\
\hline Sikap pada makanan organik (ATB): & & & \\
\hline ATB1 & 0,92 & 0,85 & & \\
\hline ATB2 & 0,92 & 0,85 & & 0,68 \\
\hline ATB3 & 0,91 & 0,83 & & \\
\hline ATB4 & 0,91 & 0,83 & & \\
\hline Gaya hidup sehat (GH): & & & & \\
\hline GH1 & 0,88 & 0,77 & & \\
\hline GH2 & 0,86 & 0,74 & & \\
\hline GH3 & 0,82 & 0,67 & & \\
\hline GH4 & 0,77 & 0,59 & & \\
\hline GH5 & 0,78 & 0,61 & & \\
\hline
\end{tabular}

Sumber: Data diolah, 2013

Berdasarkan tabel 2 di atas dapat diketahui bahwa koefisien reliabilitas komposit untuk masing-masing variabel yaitu 0,95 (nilai orientasi alami manusia), 0,94 (sikap pada makanan organik) dan 0,88 (gaya hidup sehat). Semua variabel berada di atas nilai penerimaan batas reliabilitas yaitu nilai minimum 0,7. Nilai ekstraksi varian berada pada tingkat batas penerimaan yaitu nilai minimum 0,5 (El Qadri \& Wijaya 2012).Variasi nilai yaitu 0,82 (nilai orientasi alami manusia), 0,84 (sikap pada makanan organik) dan 0,68 (gaya hidup sehat).

\section{Uji Kesesuaian Model Persamaan Struktural}

Hasil uji kesesuaian model menggunakan chi-square, CMIN/DF, GFI, AGFI, RMSEA, TLI, CFI dan ECVI diringkas sebagai berikut: 
Tabel 3.

Hasil Goodness of Fit Model Pengukuran

\begin{tabular}{|l|c|c|c|}
\hline \multicolumn{1}{|c|}{ Indeks } & Cut off Value & Hasil & Evaluasi Model \\
\hline Probability & $\geq 0,05$ & 0,324 & Baik \\
\hline CMIN/DF & $\leq 2,00$ & 1,067 & Baik \\
\hline GFI & $\geq 0,90$ & 0,947 & Baik \\
\hline AGFI & $\geq 0,90$ & 0,925 & Baik \\
\hline RMSEA & $\leq 0,08$ & 0,018 & Baik \\
\hline TLI & $\geq 0,90$ & 0,998 & Baik \\
\hline CFI & $\geq 0,90$ & 0,998 & Baik \\
\hline
\end{tabular}

Sumber: Data diolah, 2013

Tabel 3 menunjukkan bahwa model penelitian secara keseluruhan fit. Secara keseluruhan nilai Chi square dengan probabilitas sebesar 0,324 > 0,05 menunjukkan keseluruhan model fit (Overall goodness-of-fit). Selain itu setelah diuji kecocokannya nilai RMSEA, GFI, AGFI, TLI, dan CFI dibandingkan nilai acuan (cut off value) persamaan model struktural hasilnya baik.

\section{Uji Hipotesis}

Hasil uji kausalitas model dalam model jalur penelitian ini secara lengkap sebagai berikut:

Gambar 1.

Model Jalur

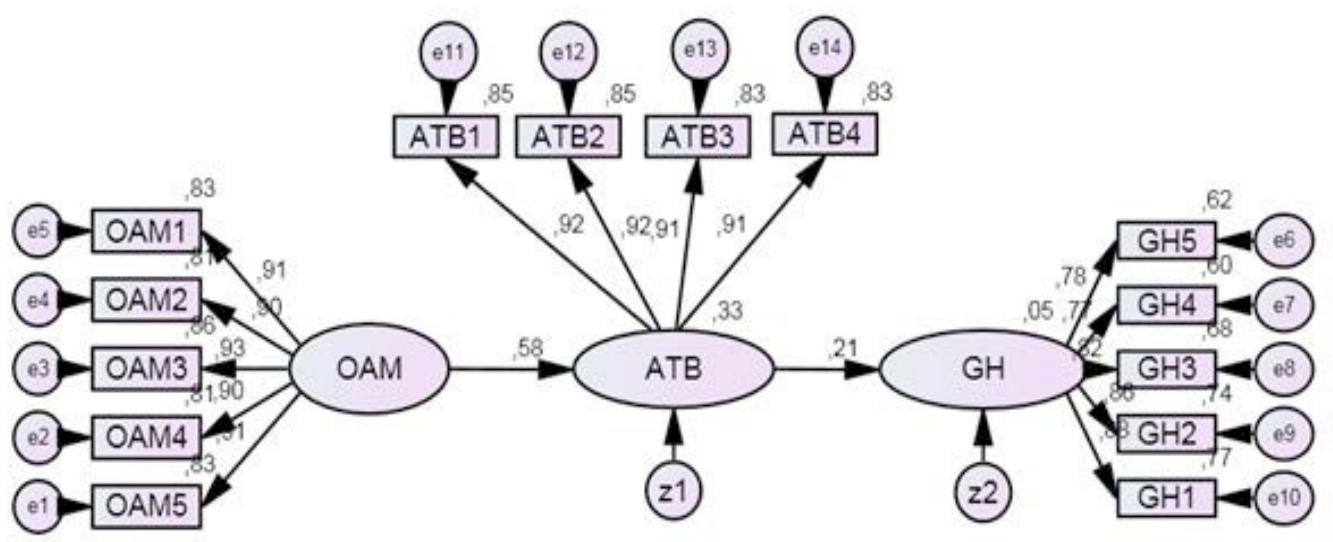

Hasil bobot regresi antar variabel laten yang sering disebut sebagai estimasi loading factors atau lambda value dapat digunakan untuk menganalisis uji kausalitas variabel. Berdasarkan signifikansi nilai CR (Critical Ratio) dengan nilai probabilitas $(\mathrm{p})=0.05$. Hasil bobot regresi uji kausalitas sebagai berikut: 
Tabel 4.

Evaluasi Bobot Regresi Uji Kausalitas

\begin{tabular}{|c|c|c|c|c|}
\hline Hipotesis & Variabel & Estimasi & CR & P \\
\hline Hipotesis 1 & OAM $\rightarrow$ ATB & 0,571 & 8,797 & 0,000 \\
\hline Hipotesis 2 & ATB $\rightarrow$ GH & 0,123 & 2,846 & 0,004 \\
\hline
\end{tabular}

Sumber: Data diolah, 2013

Keterangan:

$\mathrm{OAM}=$ Nilai orientasi alami manusia

ATB $\quad=$ Sikap pada makanan organik

GH = Gaya hidup sehat

Penjelasan lebih lanjut analisis evaluasi bobot regresi tersebut dapat dijelaskan bahwa variabel nilai orientasi alami manusia mempengaruhi sikap pada makanan organik secara positif dan signifikan dengan tingkat signifikansi sebesar 0,000 lebih kecil dari nilai probabilitas $\leq 0,05$. Dengan demikian hipotesis 1 diterima. Variabel sikap pada makanan organik mempengaruhi gaya hidup sehat secara positif dan signifikan dengan tingkat signifikansi sebesar 0,004 lebih kecil dari nilai probabilitas $\leq 0,05$. Dengan demikian hipotesis 2 diterima. Besarnya kontribusi variabel secara simultan terhadap variabel lainnya diringkas dalam tabel 5 sebagai berikut:

Tabel 5.

Koefisien Determinasi

\begin{tabular}{|l|l|c|}
\hline Variabel Independen & Variabel Dependen & Sumbangan efektif \\
\hline Sikap terhadap makanan organik & Gaya hidup sehat & $4,5 \%$ \\
\hline Orientasi alami manusia & Sikap pada makanan organik & $33,4 \%$ \\
\hline
\end{tabular}

Sumber: Data diolah, 2013

Berdasarkan tabel 5 di atas dapat diketahui bahwa variabel sikap pada makanan organik memiliki peran sebesar 4,5\% terhadap gaya hidup sehat. Variabel nilai orientasi alami manusia memiliki peran sebesar 33,4\% dalam menjelaskan sikap pada makanan organik.

\section{Pembahasan}

\section{Peran Nilai Orientasi Alami Manusia terhadap Sikap pada Makanan Organik}

Hasil analisis data menunjukkan nilai orientasi alami manusia berpengaruh positif dan signifikan terhadap sikap pada makanan organik. Hasil temuan penelitian ini konsisten dengan hasil temuan Dreezens et al.(2005); Krystallis et al.(2008); Grunert \& Juhl (1995); Loureiro et al. (2001); Magnusson et al. (2001, 2003); Durham \& Andrade (2005); Kuhar \& Juvancic (2005); Midmore et al. (2005); Padel \& Foster (2005); Verhoef (2005); Gracia \& de Magistris (2007); Stobbelaar et al. (2007), Chen (2009); Suprapto \& Wijaya (2012a) dan 
Wijaya \& Hidayat (2011). Hasil temuan menunjukkan semakin tinggi nilai orientasi alami manusia pada konsumen maka semakin baik sikap pada makanan organik, sebaliknya semakin rendah nilai orientasi alami manusia pada konsumen maka semakin buruk juga sikap pada makanan organik.

Makanan organik sebagai produk ramah lingkungan merupakan elemen sistem keyakinan individu (Dembkowski \& Lloyd 1994). Secara spesifik, Arnould et al. (2004) dan Homer dan Kahle (1988) menjelaskan hubungan nilai dengan perilaku konsumen melalui mekanisme secara hirarki. Nilai berperan dalam membentuk sikap konsumen. Nilai merupakan pertimbangan yang fundamental bagi hubungan konsumen dengan lingkungan. Penduduk Asia memandang diri mereka sebagai bagian dari alam dan hidup harmonis dengan alam atau berorientasi pada alam (de Mooij 2004) yang disebut Chan (2001) sebagai orientasi alami manusia (Man Nature Orientation). Konsumen yang memiliki orientasi alami manusia cenderung mempertimbangkan akibat-akibat konsumsi pada lingkungan sehingga memiliki sikap ramah lingkungan (Chan 2001) dan mendukung penggunaan produk organik (Wijaya \& Hidayat 2011).

Masyarakat Indonesia yang memiliki kecenderungan kolektivis memiliki makna hidup untuk harmoni atau seimbang dengan alam (Susana 2009). Sebagai contoh pemetaan yang dilakukan oleh Susana (2009) berdasarkan konsep Koentjoroningrat menjelaskan bahwa masyarakat yang cenderung kolektivis yang ditunjukkan dengan pembangunan agraris, budaya tradisional, nilai-nilai gotong royong, hidup selaras dengan alam yang dicerminkan lewat acara-acara tradisi seperti slametan, tradisi di gunung merapi dan laut selatan, mengutamakan harmoni dibandingkan ambisi pribadi. Nilai-nilai tersebut perlu dijaga dan dilestarikan melalui jalur pendidikan.

\section{Peran Sikap pada Makanan Organik terhadap Gaya Hidup Sehat}

Hasil penelitian membuktikan adanya pengaruh sikap pada makanan organik secara positif dan signifikan terhadap gaya hidup sehat. Hasil temuan ini konsisten dengan temuan Beharrel \& MacFie (1991), Chen (2009), Gil et al. (2000), dan Suprapto \& Wijaya (2012b). Hasil ini menunjukkan semakin baik sikap konsumen pada makanan organik maka semakin tingggi kecenderungan untuk bergaya hidup sehat, sebaliknya semakin buruk sikap pada makanan organik maka semakin rendah kecenderungan untuk bergaya hidup sehat.

Sikap merupakan susunan dari keyakinan dan evaluasi terhadap perilaku. Sesuai konsep dasar teori hirarki nilai sikap perilaku menunjukkan bahwa sikap merupakan prediktor yang baik bagi berperilaku. Selain itu teori perilaku terencana menyebutkan bahwa perilaku adalah fungsi dari determinan sikap terhadap perilaku, yang merupakan dasar bagi pembentukan perilaku. Menurut Ajzen (1991) terwujud tidaknya perilaku sangat tergantung pada faktor eksternal dan internal. Faktor internal tergantung pada keyakinan dari individu dalam berperilaku dan dapat tidaknya berperilaku sedangkan faktor eksternal merupakan stimulus yang mendorong individu untuk berperilaku sehat.

Semakin positif keyakinan individu akan akibat dari suatu obyek sikap, maka akan semakin positif pula sikap individu terhadap obyek sikap tersebut, demikian pula sebaliknya (Fisbein \& Ajzen 1975). Evaluasi akan berakibat perilaku penilaian yang diberikan individu terhadap tiap-tiap akibat atau hasil yang diperoleh oleh individu. Konsumen yang memiliki sikap yang positif terhadap makanan organik berdasarkan keyakinan dan evaluasi akan mengutamakan 158 
pola hidup sehat karena makanan organik dianggap bermanfaat dan menguntungkan mereka sehingga menstimulasi gaya hidup yang berpola sehat.

\section{SIMPULAN DAN SARAN}

\section{Simpulan}

Berdasarkan analisis data dan pengujian hipotesis dapat disimpulkan sebagai berikut:

1. Terdapat kesesuaian pada model yang menggambarkan pengaruh orientasi alami manusia, dan sikap pada makanan organik, terhadap gaya hidup sehat. Hal ini didukung dengan persyaratan goodness of fit dari model. Dengan demikian model dalam penelitian ini dapat diaplikasikan dalam konteks konsumen pangan organik

2. Nilai orientasi alami manusia memiliki pengaruh positif dan signifikan terhadap sikap pada makanan organik. Hal ini berarti semakin tinggi nilai orientasi alami manusia, maka semakin baik juga sikap pada makanan organik.

3. Sikap pada makanan organik memiliki pengaruh positif dan signifikan terhadap gaya hidup sehat. Hal ini berarti semakin baik sikap pada makanan organik, maka semakin tinggi kecenderungan untuk bergaya hidup sehat.

Penelitian memberikan kontribusi yang sifatnya teoritis dan praktis dalam wujud implikasi manajerial. Variabel nilai secara parsial merupakan prediktor yang baik bagi gaya hidup sehat melalui sikap. Sikap pada makanan organik secara parsial berpengaruh terhadap gaya hidup sehat. Secara teoritis temuan ini sesuai teori hirarki nilai, sikap dan perilaku yang dapat diaplikasikan dalam perilaku konsumen organik.

Secara praktis, berkaitan dengan pengaruh nilai orientasi alami manusia, diperlukan adanya penanaman nilai yang berorientasi alami manusia melalui sosialisasi kesadaran akan perilaku ramah lingkungan. Sosialisasi kesadaran akan ramah lingkungan dapat ditanamkan dari generasi ke generasi melalui jenjang formal seperti sekolah maupun non formal seperti keluarga. Cina contohnya, penanaman filosofi dilakukan oleh pemerintah melalui jenjang formal seperti lembaga pendidikan atau sekolah maupun non-formal melalui keluarga yang dilakukan sejak usia dini hingga mengakar dalam kehidupan masyarakat. Edukasi yang berbasis ramah lingkungan perlu mendapat perhatian dari pemerintah. Penanaman nilai juga akan menyadarkan manusia pentingnya hubungan manusia dengan alam sehingga tercipta sikap yang positif pada makanan organik yang terbentuk dalam pola konsumsi sehat berbasis ramah lingkungan.

Perilaku yang memperhatikan kualitas lingkungan hidup sangat bergantung pada tingkat pengetahuan, sikap, dan nilai yang ada pada konsumen sebagai umat manusia (Mansaray \& Abijoye 1998; Chen \& Chai 2010; Said 2003). Penelitian ini memiliki keterbatasan hanya memprediksi gaya hidup sehat melalui aspek nilai dan sikap, penelitian selanjutnya dapat mempertimbangkan aspek pengetahuan secara komprehensif dalam memprediksi gaya hidup sehat.

Secara metodologi, penggunaan kuesioner sebagai alat pengumpul data memiliki banyak kelemahan. Keterbatasan berupa persepsi responden tergantung pada pemahaman butir pertanyaan yang tercantum dalam kuesioner sehingga kemungkinan terjadi perbedaan persepsi responden dengan pengukuran yang bersifat self reported sehingga kemungkinan 
terjadi responden menjawab yang tidak sesuai dengan kenyataan diri. Penelitian selanjutnya sebaiknya menggunakan mix methods dalam melakukan analisis data.

\section{DAFTAR PUSTAKA}

Adriyani, R. 2006. Usaha Pengendalian Pencemaran Lingkungan Akibat Penggunaan Pestisida Pertanian. Jurnal Kesehatan Lingkungan. 3 (1), 95-106.

Ajzen, I. 1991. The Theory of Planned Behavior. Organizational Behavior and Human Decision Process, 50, 179-211.

Arnould, E.J., Price, L.L. \& Zinkhan, G.M. 2004. Consumers. New York: McGraw-Hill.

Baker, S, Thompson, K,E.,Engelken, J. \& Huntley, K. 2004. Mapping the Values Driving Organic Food Choice: Germany vs the UK. European Journal of Marketing, 38 (8), 9951012.

Beharrel, B. \& Macfie, J, H. 1991. Consumer Attitudes To Organic Foods. British Food Journal, 93 (2), 25-30.

Bloch, P. 1984. The Wellness Movement: Imperatives For Health Care Marketers. Journal of Health Care Marketing, 4, 9-16.

Chan, R.Y.K. 2001. Determinants of Chinese Consumers Green Purchase Behavior. Psychology \& Marketing, 8, 389-413.

Chan, R.Y.K., \& Lau, L.B.Y. 2000. Antecedents of Green Purchases: A Survey in China, Journal of Consumer Marketing, 17.338-357.

Chen, T,B \& Chai, L, T. 2010. Attitude Towards the Environment and Green Product: Consumer Perspective. Management Science and Engineering, 4 (2), 27-39

Chryssohoidis, G, M.,\& Krystallis, A. 2005. Organic Consumer's Personal Value Research: Testing and Validating the List of Value Scale and Implementing a Value-Based Segmentation Task. Food Quality and Preference, 16, 585-599.

Churchill, G. A. 1979. A Paradigm for Developing Better Measures of Marketing Constructs. Journal of Marketing Research, 16, 67-73.

Dembkowski, D, S., \& Lloyd, S, H. 1994. The Environmental Value Attitude System Model. Journal of Marketing Management. 19, 593-603

De Mooij, M. 2004. Consumer Behavior and Culture: Consequences for Global Marketing. California: Sage.

Divine, R, L., \& Lepisto, L. 2005. Analysis of Healthy Lifestyle Consumer. Journal of Consumer Marketing, 22(5), 275-283. 
Dreezens, E., Martijn, C., Tenbult, P., Kok, G., \& de Vries, N, K. 2005. Food and Values; an Examination of Values Underlying Attitudes Toward Genetically Modified and Organically Grown Food Products. Appetite, 44 (1), 115-122.

Durham, C, A., \& Andrade, D. 2005. Health vs Environmental Motivation in Organic Preferences and Purchases. Paper presnted at the American Agricultural Economics Association Annual Meeting, Providence, 24-27 July.

Engel, J.F., Roger, D.B., \& Paul, W. M. 2005., Consumer Behavior. International Edition, Forth Worth : Dreyden Press.

El Qadri, Zainal, Mustafa., \& Wijaya, T. 2012. Panduan Teknik Statistik SEM \& PLS dengan SPSS AMOS. Yogyakarta: BP Cahaya Atma.

Fishbein, M., \& Ajzen, I. 1975. Belief, Attitude, Intention and Behavior: An Introduction To Theory and Research. Menlo Park, California; Addison-Wesley Publishing Company Inc.

Fotopoulos, C., \& Athanasios, K. 2002., Purchasing Motives and Profile of The Greek Organic Consumer: A Countrywide Survey. British Food Journal, 104, 730-765.

Fraj, E., \& Martinez, E. 2006. Environmental Values and Lifestyles As Determining Factors of Ecological Consumer Behaviour: An Emprical Analysis. Journal of Consumer Marketing, 23 (3), 113-144.

Gil, J.M., Gracia, A., \& Sanchez, M. 2000. Market Segmentation and Willingness to Pay for Organic Products in Spain. International Food and Agribusiness Management Review, 3 (2), 207-26.

Gracia, A., \& Magistris, T. 2007. Organic Food Product Purchase Behaviour: A Pilot Study for Urban Consumers in The South of Italy. Spanish Journal og Agricultural Research, 5 (4), 439-451.

Grunert, S.C., \& Juhl, H, J. 1995. Value, Environmental Attitudes, and Buying of Organic Foods. Journal of Economic Psychology, 16, 39-62.

Gunawan, A. 1999. Food Combining, Kombinasi Makanan Serasi. Jakarta: PT Gramedia Pustaka Utama.

Hidayat, A., \& Wijaya, T 2012. Model of Purchase Intention on Organic Food. 19th International Conference on Recent Advances in Retailing and Service ScienceMarketing, Proceeding Vienna-Austria, 9-12 July.

Homer, P.M., \& Khale, L.R. 1988. A Structural Equation Test of the Value-AttitudeBehavior Hierarchy. Journal of personality and Social Psychology, 54, 638-646.

Rifai, A., Muwardi, D., \& Rangkuti, J.R.F. 2008. Perilaku Konsumen Sayuran Organik di Kota Pekanbaru. Jurnal Industri dan Perkotaan, 12 (22).

Kasali, R. 1998. Membidik Pasar Indonesia: Segmentasi, Targeting, dan Positioning. Jakarta: Gramedia. 
Kluckhohn, F.R., \& Strodtbeck, F.L. 1961. Variations in Value Orientations. Evanston, Ill.: Row, Peterson.

Kotler, P. 2006. Marketing Management. Millennium Edition, New Jersey : Prentice Hall International, Inc.

Krystallis, A., Vassallo, M., Chryssohoidis, G. \& Perrea, T. 2008. Societal and Individualistic Drivers As Predictors of Organic Purchasing Revealed Through a Portrait Value Questionnaire (PVQ) Based Inventory, Journal of Consumer Behaviour, 7, 164-187.

Kuhar, A., \& Juvancic, L. 2005. Modelling Consumer Preferences Toward Organic and Integrated Fruits and Vegetables in Slovania, Paper presented at 97th EAAE Seminar on The Economics and Policy of Diet and Health, Reading.

Loureiro, M, J., McCluskey, J,J., \& Mittelhammer, R. C. 2001. Assesing Consumer Preferences For Organic, Eco-Labeled and Regular Apples, Journal of Agricultural and Resource Economics, 26 (2), 404-416.

Magistris, T., \& Gracia, A. 2008. The Decision to Buy Organic Food Products in Southern Italy. British Food Journal, 10, 929-947.

Magnusson, M.K., Arvola, A., Hursti, U.K., Aberg, L., \& Sjoden., P. 2001. Attitudes Towards Organic Foods Among Swedish Consumers. British Food Journal, 103, 209-226.

Mansaray, A. and Abijoye, J.O. 1998. Environmental Knowledge, Attitudes and Behavior In Dutch Secondary School, Journal of Environmental Education, 30(2), 4-11.

Midmore, P., Naspetti, S., Sherwood, A, M., Vairo, D., Wier, M., \& Zanoli, R. 2005. Consumer Attitudes to Quality Safety Of Organic and Low Input Foods: A Review. University of Wales, Aberystwyth.

Milfont, T..L, Duckitt, J., \& Wagner, C. 2009. A Cross Cultural Test of The Value-AttitudeBehavior Hierarchy, Journal of Applied Social Psychology (In Press). Diunduh melalui www.milfont.com/pubs_br.shtml tanggal 12 desember 2009.

Mowen, J. \& Minor, M. 2006. Consumer Behavior, A Framework. Englewood Cliffs, NJ: Prentice-Hall

Munarso, S.J.,Miskiyah. \& Broto, W. 2006. Studi Kandungan Residu Pestisida Pada Kubis, Tomat, dan Wortel di Malang dan Cianjur. Buletin Teknologi Pascapanen Pertanian, 2.

Noorastuti, P, T., \& Astuti, L, D, P. 2010. Awas, Buah dan Sayur Bisa Picu Gangguan Mental. Diunduh melalui http://www.vivanews.com

Padel, S., \& Foster, C. 2005. Exploring the Gap Between Attitudes and Behaviour: Understanding Why Consumers Buy or Do Not Buy Organic Food. British Food Journal, 107 (8), $606-625$. 
Said, M. A. 2003. Environmental Concerns, Knowledge and Practices Gap Among Malaysian Teachers. International Journal of Sustainability in Higher Education, 4. 305-313.

Sanjuan, A,I. Sanchez, M., Gil, J, M. Gracia, A \& Soler, F. 2003. Brakes to Organic Market Enlargement In Spain: Consumers and Retailers Attitude and Willing to Pay. International Journal of Consumer Studies, 27 (2), 134 - 144.

Schwartz, S. H., \& Bilsky, W. 1987. Towards universal Psychological Structure of Human Values. Journal of Personality and Social Psychology, 53, 550-562.

Sihombing, S.O. 2007. Predicting Environmentally Purchase Behavior: A Test of The ValueAttitude-Behavior Hierarchy. The 2nd Indonesian Business Management Conference, Jakarta, 30 Januari.

Stobbelaar, D, J., Casimir, G., Borghuis, J., Marks, I, Meijer, L., \& Zebeda, S. 2007. Adolescents Attitudes Toward Organic Food: A Survey of 15 to 16 Year Old School Children. International Journal of Consumer Studies, 31, 349-356.

Supardi, I. 1994. Lingkungan Hidup dan Kelestariannya. Edisi Kedua. Bandung: Penerbit Alumni

Suprapto, B., \& Wijaya, T. 2012a. Model of Buying Intention On Organic Food. International Conference in Marketing, Proceeding Lucknow-India, 12-14 January.

Suprapto, B., \& Wijaya, T. 2012b. Intention of Indonesian Consumers On Buying Organic Food. International Journal of Trade, Economics and Finance, 3 (2), 114-119.

Susana, T. 2009. Pengaruh Orientasi Budaya Individual, Jenis Kelamin, dan Orientasi Budaya Masyarakat Terhadap Gejala Somatisasi dan Depresi Murni. Disertasi doktor tidak diterbitkan, Fakultas psikologi UGM.Yogyakarta: Universitas Gadjah Mada.

Verhoef, P, C. 2005. Explaining Purchase of Organic Meat by Dutch Consumer. European Review of Agricultural Economics, 32, 245-267.

Verschuren, P.M. 2002. Functional Foods: Scientific and Hlobal Perspectives. British Journal of Nutrition, 88, S125-S130

Westrate , J. A. Poppel, G. van \& Verschuren, P, M. 2002. Functional Foods, Trends and Future. British Journal of Nutrition, 88, S233-S235

Wijaya, T. 2013. Sikap Terhadap Makanan Organik, Norma Subjektif, Kontrol Perilaku Konsumen Makanan Organik: Konsep dan Pengukuran”. Lantip-Jurnal Ilmu Sosial dan Ekonomi, 3 (1), 20-33.

Wijaya, T. \& Hidayat, A. 2011. Model Intensi Pembelian Makanan Organik. Call for Paper Update Ekonomi, Akuntansi dan Bisnis Indonesia, Proceeding Fakultas Ekonomi UIIYogyakarta, 28 Juni.

Williamson, J.B., Karp, D.A. \& Dalphin, J.R. 1977. The Research Craft: An Introduction to Social Sciences Methods. Boston: Little Brown and Company. 
Winarno, F.G. 2003. Pangan Organik di Kawasan Asia Pasifik, Kompas, Senin, 30 Juni 2003, 35 . 